東京都と神奈川県の移築民家における移築の理由，移築の移動距離， 移築の行われた時代とその相互関係

\title{
ABOUT THE REASON, MIGRATION LENGTHS AND AGE, INTERRELATIONSHIPS OF REMOVING AND RECONSTRUCTION OF THE FOLK HOUSE IN TOKYO AND KANAGAWA PREFECTURE
}

\author{
平山䏍 男* \\ Ikuo HIRA YAMA
}

\begin{abstract}
There is no difference between Tokyo and Kanagawa pref., in the "age" distribution about removing and reoonstruction of the folk house. 19 century latter terms, the "reason" of "fire disaster" is most. The "distance" is many from neighboring area, but 20 century first half decreased removing and reconstruction distance. Removing and reconstruction was done in order to obtain the residence quickly and cheaply. As the prerequisite, it is thought that the similar type residence was distributed widely inside area.
\end{abstract}

\section{Keywords : Folk house, Removing and reoonstruction, Fire}

民家、移策 火赑

\section{1. はじめに}

前稿等においては東京都、神奈川県の全域における民家建築 の調查結果を悉皆的に検証することによって、当該地域において は 2,256 棟の民家について調查の報告があり、この内 284 楝、 的 $13 \% 、 8$ 軒に 1 軒か移筑を受けた民家であることを示した 本稿では前稿において抽出した資料に基づき、移筑民家の実態 の内、移築の理由、移淛の移動距離、移築の行われた時代につい て、その各々の事象の検討に加兑、相互の関係を考察することに より、民家の移筑について時代的な特性と民家移築の持った意味 を考察するものである。

\section{2. 既往の研究}

民家の移策についての既往研究は前稿でも述へた通りである が、総括的に概要を述へたものは少ない。その中で移策の理由に ついて草野和夫は、農民の生活困穿之家屋教の売買が民家の移策 と強く関你すると指摘した 2。確かに後述するように民家の移策 にはそのような例も見られるものの、それが理由の全てではなく、 移築は昭和戦期まで見ることができた。また、移築民家の移動距
離については富山県佐伯家の事例を投った宮澤智士によるもの など幾つかの個別例が挙げられ、また各民家調査報告書などにお いても断片的に移筑前の場所の聞取りか紀録されるものの、それ が具体的にどの程度の距離で、それにどのような意咮があるのか の指摘は従来見られない。

\section{3、尼家が移策された时代、移策の理由、移策の移轨足目}

東京・神奈川地域における民家の移築事例 284 棟は表 1 に示 した通りである。以下では表 1 に示した資料に基づき、当該地 域における民家において移築が行われた時代、移築の理由、移筑 の移動距離（以下、適宜「時代」、理由」、距離」と称する）に ついての䫁向を先す個別に概観しておきたい。

\section{3-1 民家の移策が行われた「時代」}

東京・神奈川地域において民家の移案が行われた時代につい て立前稿において既に一部を考察した。これらによれは移築民家

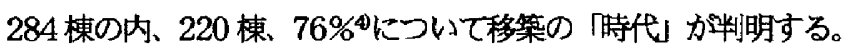
世紀前後半の 50 年ごとにおける区分では、時代」が判明する 220 棟の $88 \%$ に当たる 194 棟が 19 世紀後半〜20 世紀前半の 100

・長岡造形大学造形学部瑔境デザイン学科 教授・博士(工学) Prof., Dept. of Environmental Design Faculty of Design, Nagaoka Institute of Design, Dr. Eng. 


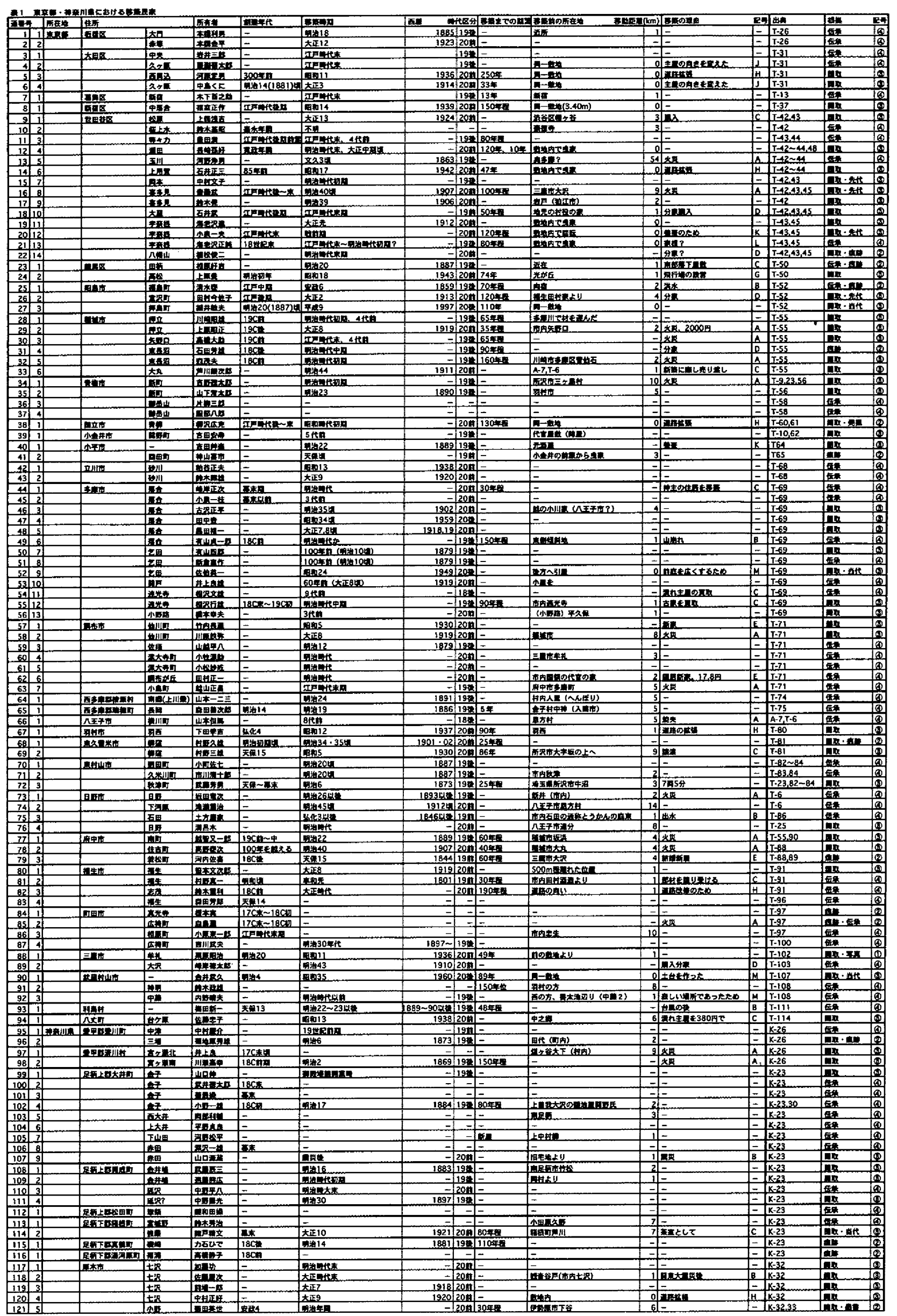




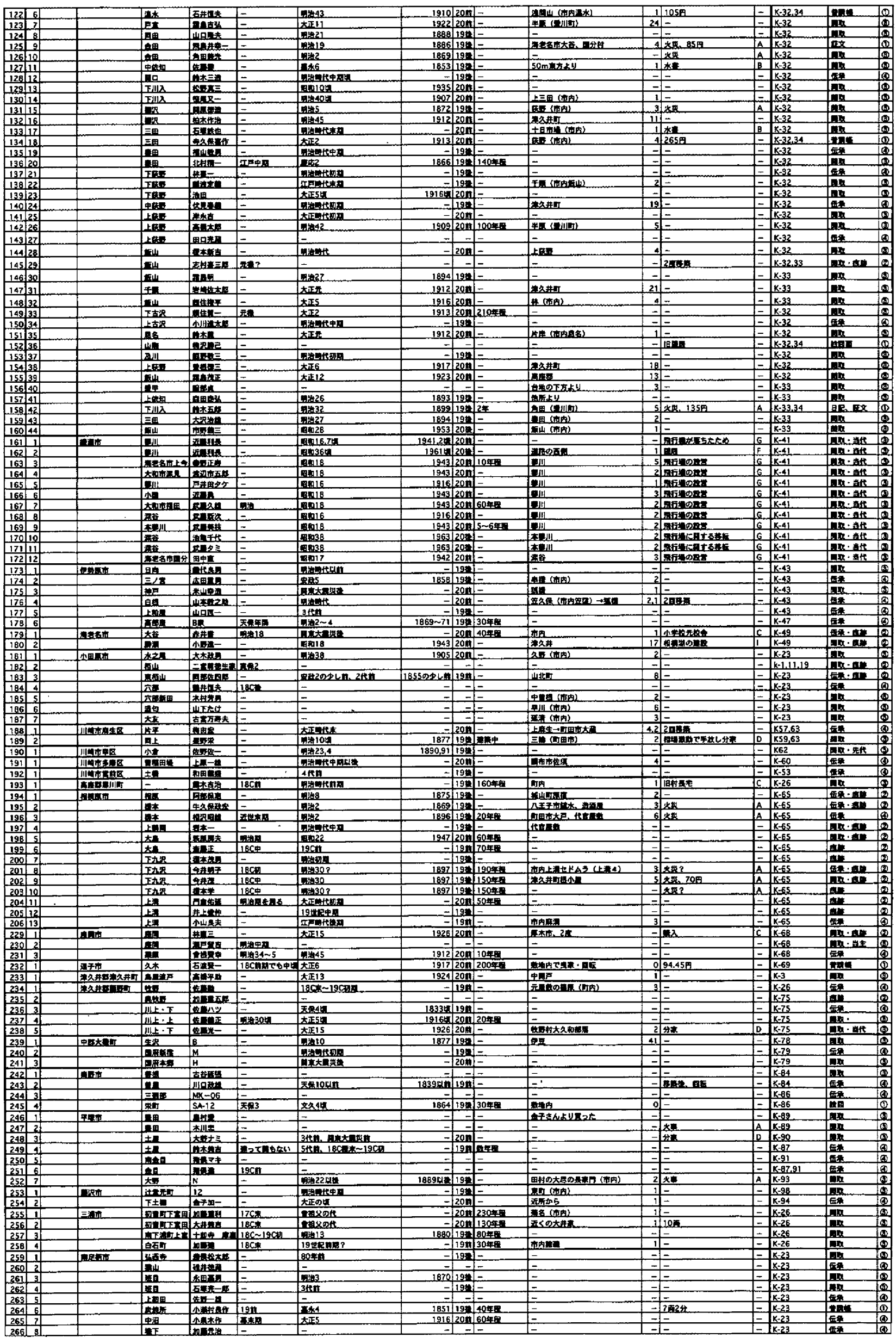




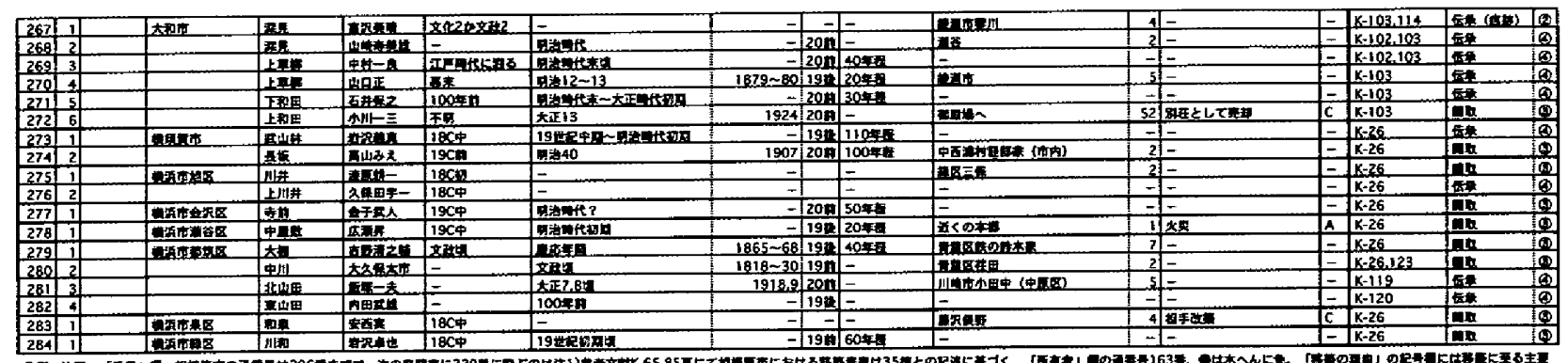

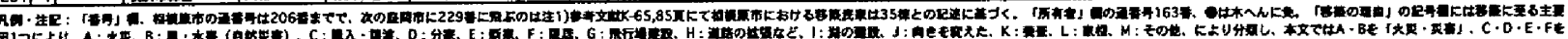

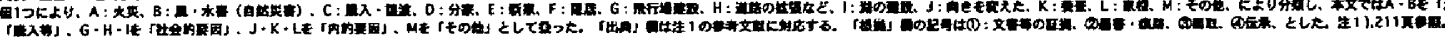

表2 民家移案の行われた「時代」

\begin{tabular}{|c|c|c|c|c|c|c|}
\hline \multirow[t]{2}{*}{ 「時代」 } & \multicolumn{2}{|c|}{ 全 体 } & \multicolumn{2}{|c|}{ 東京都 } & \multicolumn{2}{|c|}{ 神奈川県 } \\
\hline & [件] & {$[\%]$} & [件] & {$[\%]$} & [件] & [\%] \\
\hline 18C律半 & 2 & 0.9 & 2 & 2.3 & 0 & 0.0 \\
\hline 19C前半 & 16 & 7.3 & 5 & 5.8 & 11 & 8.2 \\
\hline 19C後半 & 91 & 41.4 & 34 & 39.5 & 57 & 42.5 \\
\hline 20C前半 & 103 & 46.8 & 41 & 47.7 & 62 & 46.3 \\
\hline 20C後半 & 8 & 3.6 & 4 & 4.7 & 4 & 3.0 \\
\hline 合部 & 220 & 100.0 & 86 & 100.0 & 134 & 100.0 \\
\hline
\end{tabular}

\begin{tabular}{|c|c|c|c|c|c|c|}
\hline \multirow{2}{*}{ 「理由」 } & \multicolumn{2}{|c|}{ 全 体 } & \multicolumn{2}{|c|}{ 東京都 } & \multicolumn{2}{|c|}{ 神奈川県 } \\
\hline & [件] & {$[\%]$} & [件] & [\%] & [件] & [\%] \\
\hline 火事・炎軍 & 35 & 39.3 & 17 & 35.4 & 18 & 43.9 \\
\hline 周入䉘 & 27 & 30.3 & 17 & 35.4 & 10 & 24.4 \\
\hline 社会整偖 & 19 & 21.3 & 6 & 12.5 & 13 & 31.7 \\
\hline 内的要因 & 5 & 5.6 & 5 & 10.4 & 0 & 0.0 \\
\hline その他 & 3 & 3.4 & 3 & 6.3 & 0 & 0.0 \\
\hline 合时 & 89 & 100.0 & 48 & 100.0 & 41 & 100.0 \\
\hline
\end{tabular}

年間に集中する。また、19 世紀前半以前の記録・伝承は残りづ らく、20 世紀後半以後は移策が行われなくなったと考えられた。

なお、表 2 に東京都、神奈川県におけ洔代」の分布を示 したが、両都県間で差異はほとんど見られない。これらから両都 県において、「時代」的にはほほほ等しく民家移築の数量が推移し たと判断することができる。

\section{3-2 民家移築の「理由」}

284 棟の移築例において「理由」か判明するのは $31 \%$ にた る 89 例であった。詳細に見ると、民家移筑の理由の主要因 ${ }^{5}$ と して最も多く挙げられたのは火火炎後における家屋取得のための民 家移築で、理由」の判明する 89 例中 27 例、30\%に達した。

次いで「理由」で多いのは家屋の購入・誶渡が 15 例 $17 \%$ 。 飛行場の建設によるための家屋移築が 12 例 14\%で、以上の理 由が $10 \%$ 越える比較的高い割合を示した。以下、風・水害及 び地震を含む自然災害によるものと分家時の住宅取得が各 8 例 $9 \%$ 、道路拡張による移築が 6 例 7\%と続く。加えて新居のため とするものが 3 例 $3 \%$ 、主屋の向きを変えた、養蟫のためが各 2

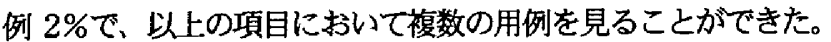
なお、荃䖽のための移築は実数こそ少ないものの羽村町史には

一般農家では、古家を買うことが多く、明治末期から大正に かけての養曐盛期には、他村から䖯室用の古家を買った人も いた。

との記述を見ることができた。

一方、関係する要因を整理すると、火災及び自然災害に際して

\begin{tabular}{|c|c|c|c|c|c|c|}
\hline \multirow{2}{*}{ 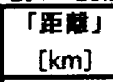 } & \multicolumn{2}{|c|}{ 全 体 } & \multicolumn{2}{|c|}{ 東京邚 } & \multicolumn{2}{|c|}{ 蚛克川是 } \\
\hline & [件] & {$[\%]$} & [件] & {$[\%]$} & [件] & {$[\%]$} \\
\hline 0 & 16 & 10.5 & 13 & 21.3 & 3 & 3.3 \\
\hline 1 & 39 & 25.7 & 16 & 26.2 & 23. & 25.3 \\
\hline 2 & 31 & 20.4 & 7 & 11.5 & 24 & 26.4 \\
\hline 3 & 14 & 9.2 & 5 & 8.2 & 10 & 11.0 \\
\hline 4 & 13 & 8.6 & 5 & 8.2 & 8 & 8.8 \\
\hline 5 & 11 & 7.2 & 5 & 8.2 & 6 & 6.6 \\
\hline 6 & 5 & 3.3 & 1 & 1.6 & 3 & 3.3 \\
\hline 7 & 3 & 2.0 & 0 & 0.0 & 3 & 3.3 \\
\hline 8 & 4 & 2.6 & 3 & 4.9 & 1 & 1.1 \\
\hline 9 & 3 & 2.0 & 2 & 3.3 & 1 & 1.1 \\
\hline 10 & 2 & 1.3 & 2 & 3.3 & 0 & 0.0 \\
\hline $11 \sim 20$ & 6 & 3.9 & 1 & 1.6 & 5 & 5.5 \\
\hline $21 \sim 30$ & 2 & 1.3 & 0 & 0.0 & 2 & 2.2 \\
\hline $31 \sim 40$ & 0 & 0.0 & 0 & 0.0 & 0 & 0.0 \\
\hline $41 \sim 50$ & 1 & 0.7 & 0 & 0.0 & 1 & 1.1 \\
\hline $51 \sim$ & 2 & 1.3 & 1 & 1.6 & 1 & 1.1 \\
\hline 合比 & 152 & 100.0 & 61 & 100.0 & 91 & 100.0 \\
\hline 平均 & \multicolumn{2}{|c|}{$4.4 \mathrm{~km}$} & \multicolumn{2}{|c|}{$3.7 \mathrm{~km}$} & \multicolumn{2}{|c|}{$4.8 \mathrm{~km}$} \\
\hline
\end{tabular}

の住居取得に伴う移筑の 2 要因を「火災 - 災害」、家屋の購入 僙渡、分家に際して、新居として、隠居のための移築とした 4 要 因を「購入等、飛行場の建設、道路の拡張、湖の建設に伴う住 居の移筑である 3 要因を「社会的整備、主屋の向きを変えた、 盖虫のため、家相のために移筑を行った 3 要因を「内的要因小、 その他を「その他」と大項目で分類すると、各々 $39 \% 、 30 \% 、 21 \%$ 、 6\%、3\%とすることができた。

以上のように当該地域においては「必災・災害」を理由とする 民家の移勧が最も多く、以下「購入等」、社会的整備小、内的要 因」の理由による移築の行われたことが判明した。

なお、東京都と神奈川県で比較すると、表 3 に示したように 東京都では「購入等」の割合がやや高く、神奈川県では「火炎・ 災害、「社会的整備」の割合が比較的多かった。

\section{3-3 民家移築の移動「距離」}

284 棟の移筑例の内、移築前の所在地力判明する事例は $54 \%$ に当たる 150 棟 152 件で、これを表 $1 の$ 移策前の所在地」欄 に記した。そして「移笻前の所在地」と調查した民家の所在地間 の距離を求め「移動距離」の欄に示した。「移動距離」は移筑さ れた民家の現所在地と「移策前の所在地」間の直楾距離を地図上 で計測し、小数点以下を四捨五入して示した。なお、同一敷地内 での移動「距離」は’0km、“近所から”とある場合は $1 \mathrm{~km}$ の移 動「距離」とした。以上を平均すると移筑前の所在地が判明する 事例に打放筑民家の平均移動「距離」は $4.4 \mathrm{~km}$ である。こ れは徒歩によれば 1 時間強て移動することのできる比較的至近の 
距離で、所在地の判明する 153 件中 114 棟、75\%が平均以下の 「距離」となった(表4)。

なお、地域別では、東宗都が $3.7 \mathrm{~km}$ 、神奈川県が $4.8 \mathrm{~km}$ の平 均移動「距離」であり、神奈川県の方が 2 割程長い傾向が見ら れた?。

\section{4，民家移策における各考察钼点相互の間係}

民家の移築にお计る「時期、「理由」、「距離」について各事 象における傾向は上に示した通りであるが、各事象相互の関係、 則ち「理由」の時代的変遷、理由」と「距離」の関係、「距離」 の時代的変遷について、資料間の整理を通して考察を加えて行き たい。

\section{4-1 民家移策「理由」の時代的変逗}

民家移筑の「理由」全体では「火災・災害」によるものが最 も多く、「理由」の判明するものの約 3 割を示したが、各時代を 通して常にそのような傾向が見られたのであろうか。「理由」と 「年代」がともに判明する 85 例について、雨者の関係を見て行 きたい。

年代である程度事例数の多い 19 世紀後期と 20 世紀前期で比 較してみると、 19 世紀後期では移策理由の明らかとなる 33 例 中、 $2 / 3$ を越える 23 例、33 例に対して $70 \%$ 移策「理由」が 「火災・災害」によるものであり、「購入等」は 6 例 $18 \%$ 、「社 会的整備」は事例自体か存在しない。このように 19 世紀後期に おける「理由」は「火炎・災害」が多くを占め、これに加え「購 入等」によるものが散見される。このような傾向は相模原におけ る民家調查でも

移筷は明治期にしばしば起こった大火のあとなどに集中的に行われ た場合が多认が、そのほかにも比較的定常的に行わ机ていたようで ある

とされるものの、ここでは民家移策の時代的な変遷についての指 摘はない。

一方、これが 20 世紀前期になると 42 例中、「火炎・炎害」は 7 例、 42 例中 $17 \%$ 乙激堿し、替わっては 購入等」が 16 例 $38 \%$ ， 「社会的整備」が 17 例 40\%と潡增し、「理由」の傾向が大きく 異なつて来る。

以上、グラフ 1 に示したように民家の移筑は 19 世紀後期にお いては「火災・災害」後の住宅再建や「購入等」がその主要な理 由と見なせたか゚、20 世紀前期以後は、新築に比べ容易な住宅移 動の方法として、近代的な理由である飛行場の建設や道路の拡幅 など「社会的整備」を要因とした民家の移策が多く行われたと見 ることができるのである。

\section{4-2 民家移策「理由」と「距舴」の関係}

民家移筑の「理由」と「距離」がともに判明するのは 284 棟 の移築例の内 $25 \%$ に当たる 72 例である。

ここで「理由」と「距離」相互の関係を見ると、「火災・災害」 の 28 例にお讨る平均の移動「距離」は $5.5 \mathrm{~km}$ 、「購入等」の 19 例は $5.4 \mathrm{~km}$ とほほ類似した数值を示すことがかかる。一方、「社 会的整備」の 18 例は平均の移動「距離」が $2.6 \mathrm{~km}$ 之、「次災・ 災害」及び「購入等」にみられた半分に満たない。これは「社会 的整備」の 18 例中 4 例が道路の执張に伴亏敷地内移動であり、
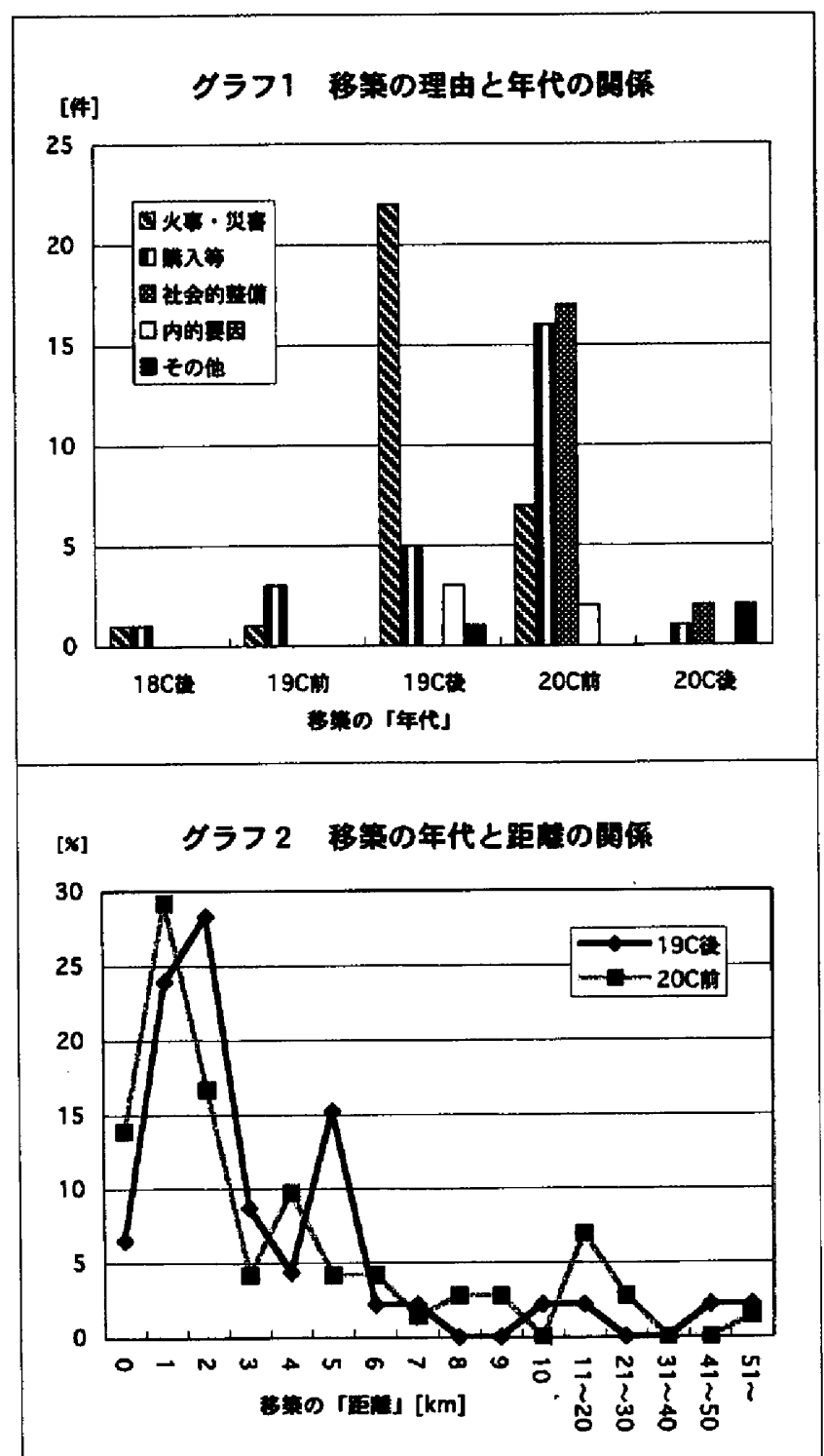

移動「距離」が $0 \mathrm{~km}$ に留まることが大きな要因として挙げられ るだろう。社会的整備」の理由による移策では相模湖の建設で $17 \mathrm{~km}$ を移動した事例 1 件も見られるが、厚木飛行場建設に際 する移動 10 件では 7 件が $2 \mathrm{~km}$ 以下、平均すると $2.4 \mathrm{~km}$ の移動 距離で、比較的近距離における建物の移動が多い。

\section{4-3 民家移策距睢の時代的变逗}

民家の移筑「距離」と「時期」がともに判明するのは 284 棟 の移勧例の内 $48 \%$ に当たる 136 例である。1世紀を前後の 50 年ごとに区切ってみると事例が多いのは 19 世紀後期の 46 例と 20 世紀前期の 72 例である。両者を平均すると 19 世紀後期が $5.0 \mathrm{~km} 、 20$ 世紀前期が $4.4 \mathrm{~km}$ となり、後者の方が前者に対し て 0.6km、12\%減少している。これは㲘述したように、20 世紀 前期なって移動の距離が比較的短い「社会的整備」に伴う民家の 移筑が行われるようになったことが要因として挙げられようげ ラフ 2)。

\section{5. 民家移策の意}

民家において移築が新築に勝る利点は、既に材料の刻みが終わ 
っていることである。つまり、民家の移策に際しては材料を加工 するための時間と労力を省くことが可能である。そのため火災や 災害後など多くの家財とともに明日住むための住宅をも失った場 合、一刻でも早く、しかも少しでも安価な住宅を容易に得るため の方策として民家の移策が多く行われたと考えることができるの である。

また，火災や災害に次ぐ理由の数量が挙げられた分家や新家、 隱居に際して行われた民家の移築や古家の買い取りも、新策に比 べ安価な住宅を、迅速に建築するための手殷として利用されたと 考えることができる。

一方、移策民家の平均の移動「距離」は $4.4 \mathrm{~km}$ であり、ここ には移動「距離」の判明する $75 \%$ が合まれた。これは徒歩によ りほほ 1 時間で移動することのできる近距離である。近代以前の 移策において材の移動は河川で舟を用いる 9以外、陸上において

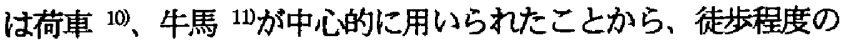
速度による材の移動であったと考えられる。トラックの利用は昭 和戦前期に確認されるものの一部に過ぎず、この時期でも牛車が 併用された ${ }^{12}$ 。また、材の移動に際しては一日に複数回往復す る場合もあり 13)、そのような観点からも徒歩 1 時間程度の距離 における移勧が多数を占めたのであろう。即ち、移筑の目的を上 に挙げた安価な住宅の迅速な供給という点に置くのであれば、移 動「距離」も短い方が経斎的に有利で、運搬手段が炣車等に限ら れた近代以前は、徒歩 1 時間圈内における移築が多数を占めた ものと考元られる。

このように見てくると、民家の移築とは地域社会の中で育まれ た、安価で且つ迅速に住宅を得るためのシステムと見做すことが できるのである。

\section{6. おわりに}

以上、東京都、神奈川県に拈ける移築民家についての考察は次 のようにまとめることができよう。

1）民家移築の行われた「時代」の分布は両都県間で差異はほと んど見られない。

2）民家移筑の「理由」では19 世紀後期においては「火炎・災 害」に際しての件数力際立って多く、20 世紀前半になって「社 会的整備」、購入等」を理由とする件数が増加した。

3）民家移策の移動「距離」は徒歩 1 時間圈内と見なせる近隣地 域からのものが多数を占めたが、20 世紀前半になって「社会的 整備」を要因とする同一敖地内における移築が増加したため移築 の移動距離は减少した。

4）民家の移策とは、新策に比較して迅速で安価に住宅を得るた めの方策として行われたと考えることができる。

\section{注}

1) 拙稿 : 東京都と神奈川県における柞家の移策楝数と地域性について、 日本建学会計画系論文集 592、209 215 頁、平成 17(2005).6。 なお、この論考 210 頁で東京都・神奈川県地域においては “2,259 棟 の調查民家の報告があり、この内少なくとも284 棟、13\%《中略》の民 家か移策を受けた”としたが、揭载後、再調䍒を実施したところ、東京都

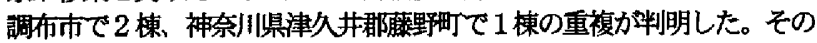
ため、当敫部分は 2,256 棟の調查民家の報告があり、この内少なくとも 284 棟、13\%《中略》の民家か移築を受けた”と改めたい。併せて 209 頁、
英文要䄪中、“2,259”とある部分を “2,256”に、210 頁、“多库地方て では 《中略》587 㤓の調查民家があり”とある部分を“多库地方つで〈中 略》585 棟の調查民家があり”、“神奈小県では 1,379 棟の調查民家中” とある部分を“神奈川県では 1 ,378 棟の調查民家中”に、表 1 の東京都 調布市の根を調查民家 A : 30 棟、移勧民家 B : 7 棟、B/A×100:23.33\%、

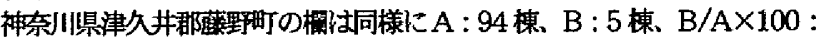

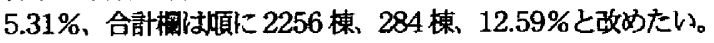
2) 草野和夫：東北民家史研究，中央公論美術出版、53～58 頁、平成 3(1995).4、及ひ 草野和夫 : 近世民家の成立過程、中央公諭美術出版、 180 183 面、平成 7(1995).2。

3 宮澤智士 : 富山県一農家 (佐伯家) の明和年間の家作とその文書、日 本建筑学会論文集 193、66 74 頁、昭和 47(1972).3。なお、佐伯家の場 合、移案の距離は “10km 程”とする。

4) 以後、割合は小数点以下を四捁五入し、距踓」の平均ては小数点第 1 位以下を四愇五入して示した。なお、表 2〜4では小数点第2 位以下を四 愇五入したため、百分率の合計は必ずしも $100 \%$

จ「理由」は表 1 凡例䧓の主要因により分類し、重複はない。

6) 注 1)、考文献 T-79 羽村町史、761 頁

ク東京都の方が移睆距離を $0 \mathrm{~km}$ とする敷地内における移動が 13 件と、 神奈川の 3 件に対して多く、これか平均移野距離の数値を押し下げる理 由の 1 つとして举げられよう。また、神奈川県厚柿、相模原市では移 策前の敷地を「津久井」とするものが目立った。厚木市の場合はやや長い 移動距離となるが、匝柿と津久井町は相模川の下流と上流の位圈関係と なる。具体的な指摘はなかったが、川を介しての材の移動か推察される。 8) 注 1)、参考文献 $\mathrm{K}-65$ 相模原の民家、85 頁。

9) 注 1)、考文献 $\mathrm{K}-65$ 相模原の民家、220 頁。注 1)、参考文献 $\mathrm{K}-34$ 厚木の民家 3、166 頁。なお、後者の北村家における移築は物圆について のものである。

10）注 1)、参考文献 $\mathrm{K}-34$ 㚖木の民家 $3 、 175$ 頁。なお、この座本家にお ける移築は藏についてのものである。

11) 注 1)、参考文献 $K-65$ 相模原の民家、230 頁。

12) 注 1)、参考文献 $\mathrm{K}-41$ 綾瀨市史民俗調查報告書 7、279 頁。

13）迬 1)、参考文献 K-34 厚木の民家 3、186 頁。 